\title{
Unemployment in Nigeria: A Time Bomb Waiting To Explode: Issues, Diagnoses and the Way Forward
}

\author{
Chiazor, I. A. PhD \\ Department of Sociology \\ Covenant University, Ota, Ogun State, Nigeria \\ Ozoya, M. I. PhD \\ Department of Sociology \\ Covenant University, Ota, Ogun State, Nigeria \\ Udume, $M$. \\ Department of Sociology \\ Covenant University, Ota, Ogun State, Nigeria
}

\begin{abstract}
The incidence of unemployment in Nigeria in this 21 st century is alarming. Over $80 \%$ of graduates from higher institutions in Nigeria are unemployed, this is in spite of their qualifications. The inability of the higher educational institutions to meet the needs of these graduates, as well as promote their economic self- reliance and self- sufficiency has resulted in massive unemployment in Nigeria. Unemployment constitutes a serious developmental problem and is increasing at an alarming rate all over Nigeria. It hinders the growth of the economy as it affects the socio-economic and political aspects of life. Unemployment leads to poverty. The paper examines the causes of unemployment in Nigeria and its effects on the economy. It identifies those who are mostly affected by the unemployment scourge. This thesis relied mainly on secondary sources of data gleaned from existing literature on the causes of unemployment and suggests possible solutions to the unemployment bomb that is waiting to explode in Nigeria. The paper believes that education is critical to making Nigerian youths more employable. It also holds the view that there is need for the army of the unemployed in Nigeria to embrace skill acquisition. Furthermore, the agricultural sector must be transformed as this will enhance their choice base and bring about massive job opportunities in that sector.
\end{abstract}

Keywords: unemployment, underemployment, poverty, Crime rates, Nigeria, Youth

\section{INTRODUCTION}

Nigeria is a country in West Africa that shares land borders with the republic of Benin in the West, Chad and Niger republic in the North and Cameroon in the east. Nigeria is the most populous country in Africa and is also termed the ninth most populous country in the world. From time immemorial, the subject of unemployment has always been an issue of great concern to the economists, policy makers and economic managers, giving the devastating effect of this phenomenon on individuals, the society and the economy at large. In Nigeria, unemployment is regarded as one of the most challenging economic problem facing the federal government. Unemployment according to ILO, is among the biggest threats to social stability in many countries (including Nigeria), putting the global rate at $12.6 \%$ (ILO, 2012). According to Udu \& Agu (2005), unemployment is "a situation in which persons capable and willing to work are unable to find suitable paid employment". 
According to a 2009 World Bank Report, 40 million (28.57\%) of the country's employable people are unemployed. The figure, according to the same World Bank, rose to 50 million a year later (Daily Trust, 2009). The consequences of rapid growth of youth unemployment and underemployment are naturally grave, and these are manifested in the ever growing pockets of conflicts, youth restiveness and militancy (Niger Delta youths; Movement for Actualization of Sovereign State of Biafra, Oduduwa People's Congress; Boko Haram scourge, etc.). Participation in criminal activities like kidnapping, abduction, drug abuse, armed robbery, political thugs, vandalization of oil pipelines and National Power holding installations, and other criminal activities and/or delinquent behaviour remains the only option for the idle and unemployed youths. Nigeria's massive unemployment not only poses a threat to its development, but also to the security and peaceful co-existence of her citizens. Moreover, it breeds excruciating poverty, the type majority of Nigerians are currently going through.

In 2014, the Nigerian Immigration Services advertised for job openings for 5,000 applicants. About 500,000 applicants applied online after paying a fee of 1,000 naira. Screening exercise held in selected stadia across the nation. As a result of the massive influx of applicants, stampede ensured in most of the stadia that resulted in loss of lives. In compensation, the Federal employed three persons from each of the bereaved families (Obiagwu, 2014). Also in September 2016, the Federal Internal Revenue Service advertised for 500 vacancies and 700,000 applied for this job placement (Vanguard, 2016). This scenario further lends credence to the unemployment crisis Nigeria is currently grappling with (NBS, 2016).

\section{STATEMENT OF THE PROBLEM}

Unemployment has assumed an epidemic dimension and is ravaging both the rural and urban communities in the Nigeria. Majority of the unemployed, particularly youths can be seen vending in the informal sector. It is an open secret to see university graduates of engineering, the sciences, and other programmes selling GSM, recharge cards on our streets. This disguised unemployment and under employment is certainly not healthy for the economy. In the short term, they seem to be employed, but the resources used in training these unemployed youths from various tertiary institutions would have gone to waste, if they cannot find employment in the medium and long terms. There are graduates from the country's tertiary institutions that have been searching for employment in the last eight years. Added to this class is an army of secondary and primary school leavers, and countless millions of uneducated youths who daily roam the streets for none existent jobs.

Those who cannot find menial jobs or be active in the informal sector have joined the gangs of armed robbers and kidnappers. The dangers of kidnapping and other serial social vices is that it can become so lucrative that they may remain as permanent employment for those unemployed. Some who have taking to kidnapping, may never seek wage/salary employment even if the jobs become available. This mass of the unemployed have become ready tools in hands of all types of insurgent groups in Nigeria. They form a pool from where new recruits are sourced daily by these evil groups. Commission (NPC, 2013) The Nigerian Population Commission ( NPC,2013) in its report stated that half of the population of Nigeria is made up of youths who are between 15 and 34 years of age. The unemployed and frustrated youth population is a reservoir for instability and spread of social vices (Daily Trust 14th May 2015). According to Margee Ensign, the high rate of unemployment among the youths is Nigeria's biggest challenge. She noted that with the increase in the size of the country's population, Nigeria would find it difficult to provide jobs for over 200 million young people who will live in it by 2045 (The Nation, 29th March 2016). Unemployment has become one of the fundamental developmental challenges facing Nigeria at the moment. With a very high population and 
numerous universities in Nigeria churning out thousands of graduates every year, with no ready market to employ them the wave of unemployment has assumed a crisis dimension.

The scourge of unemployment ravaging the country currently is so horrendous that it has become a "Time Bomb" waiting to explode. Nigeria's reserve army of the unemployed is undeniably a time bomb in waiting (Akpan, 2014). It should not be allowed to explode. The time to solve the crisis of unemployment is now. Tomorrow is too late .In the light of the foregoing, this paper seeks to, among other things:

- To identify the causes of unemployment in Nigeria

- To identify the consequences of unemployment on Nigeria

- And proffer possible solutions to the ravaging unemployment scourge in Nigeria

\section{SIGNIFICANCE OF THE STUDY}

Literature reveals that in some developed countries, the youth unemployment rate has witnessed an upsurge above 50 per cent. Specifically, report has shown that in low- and middle-income countries, the primary employment difficulty faced by the youth is underemployment in the informal sector. Accordingly, the International Labour Organization (ILO), estimates a minimum of 600 million jobs would need to be generated over the next ten years to absorb the current number of unemployed youths and provide job opportunities for the projected 40 million new applicants yearly (UN, 2016).

The problems caused by unemployment in Nigeria over the years, has led to down turn in the economic fortunes of the country. Today, many graduates in Nigeria are unemployed and are unable to achieve their dreams with their academic qualifications. Added to this, are millions of youths who now venture into crimes in order to survive. This study is aimed at highlighting the effects of unemployment and its attendant consequences on the development of Nigeria .It also seeks to proffer solutions to the growing wave of massive unemployment in the country.

In economics, a $5 \%$ rate of unemployment is perceived as full employment. In such an economy, the growth rate may range between 3 to 5 percent. The Nigerian economy with more than $32.6 \%$ of unemployment and underemployment shows an alarming picture of the economic crisis that Nigeria is going through right now (Proshare, 2016). Confirming these facts, the Nigerian Bureau of Statistics report for Q1 and Q2 2016 vividly captured the picture of the wave of unemployment in Nigeria this way:

there were a total of 24.50 million persons between the ages of 15-64 that were willing and able to work and actively seeking work (i.e in the labour force) that were either unemployed or underemployed compared to 22.45million in Q4 2015, and 20.73 million in Q3 2015 ... 56.1\% of Nigerians in the labour force (not entire population) aged 15-24 years were either unemployed or underemployed in Q1 2016 compared to 53.5\% in Q4 2015 while another $32.8 \%$ aged 25-34 years were either unemployed or underemployed in Q1 2016 compared to $31.3 \%$ in Q4 2015. Accordingly, out of a total youth labour force of 38.2 million (representing $48.7 \%$ of total labour force in Nigeria of $78.48 \mathrm{mn}$ ), a total of $15.2 \mathrm{mn}$ of them were either unemployed or underemployed in Q1 2016 representing a youth unemployment rate of 42.24\% (NBS, 2016). 


\section{METHODOLOGY}

This paper relied on secondary sources of data that engages archival review of challenges of unemployment and how it can be reduced in Nigeria. These data were drawn from published and unpublished sources such as newspapers, periodicals, textbooks and journals.

\section{Unemployment}

\section{LITERATURE REVIEW}

There is no universally accepted definition of unemployment. Different countries adopt definitions that are considered suitable for their local needs. However, most countries use the International Labour Organization (ILO) definition, or a variant of it to estimate unemployment (NBS, 2016). Hornby (2010) defines unemployment as "the facts of a number of people not having a job. Alanana, (2003) opines that unemployment is potentially dangerous as it sends disturbing signal to all segments of the Nigerian Society. Economy watch, (2005) reports that unemployment in Nigeria is one of the most critical problems the country is facing. The years of corruption, civil war, military rule, and mismanagement have hindered economic growth of the country. The International Labour Organization (ILO) defines the unemployed as members of the economically active population who are without work but available for and seeking work, including people who have lost their jobs or who have voluntarily left work (IBRD, 2009). Unemployment leads to increased crime rate and insecurity. According to the ILO's Global Employment Trends for Youth, 2011 Update, the global youth unemployment rate rose from 11.8 to 12.7 percent between 2008 and 2009, the largest one-year increase on record. In the ten years from 1998 and 2008, youth unemployment increased by a total of 0.2 percent or about 100,000 persons per year; but from 2008 to 2009 it increased by 5.3\%, or 4.5 million persons, in a single year. By the end of 2010, an estimated 75.8 million young people were unemployed (UN, “World Youth Report," 2012).

\section{Types of Unemployment In Nigeria}

Economists have distinguished between the various overlapping types of unemployment. Some types of unemployment in Nigeria are explained below:

1. Seasonal Unemployment: According to Udu and Agu (2005) seasonal unemployment occurs mostly in industrial sector, and in the enterprise that are seasonal in nature. Seasonal unemployment is said to occur in a situation in which people are laid off seasonally, due to the nature of the job they do, agriculture workers in developing countries may be laid off during the growing season.

2. Structural Unemployment: Structural unemployment could also results from persistent cyclical unemployment, that is, if the economy suffers from long-term low aggregate demand and in the techniques of the industry, unemployment could occur (Udu \& Agu, 2005; Harold, 2009). Structural unemployment occurs where employment in one or more industries is falling.

3. Frictional Unemployment: Udu and Agu (2005) asserted that, there is frictional unemployment when certain occupations have surplus workers in one part of the country, while vacancies for similar jobs occur and are not filled in other parts of the country. It occurs when people are temporarily out of work because they are changing jobs. This is unavoidable in an economy in which both the labour force and the jobs on offer are continually changing. Friction here refers to the incongruity between the demand for and supply of labour (Harold, 2009). This type of unemployment is always present in an economy and is more common with specialized labour.

4. Transitional Unemployment: Udu and Agu (2005) refer to this as normal unemployment, because it is of short duration. It does not harm the economy. In construction industries or contract jobs which rely heavily on manual labour, workers 
are temporarily laid off at the end of major assignments. Such workers are re-engaged when other jobs become available. Others may drift to other ongoing projects.

5. Classical Unemployment: This occurs when real wages for a job are set above the market clearing level, causing the number of job-seekers to exceed the number of vacancies. Most economists have argued that increased government intervention in the economy leads to increase in the rate of employment of a nation. For instance, the minimum wage as stipulated by Labour Law has raised the cost of unskilled or low skilled labour above the market equilibrium. This has led to a drastic reduction in the employment of these categories of labour.

6. Hidden Unemployment: Hidden unemployment is the unemployment of potential workers that does not usually reflects on official unemployment statistics, due to the way the statistics are collected. In many countries only those who have no work but are actively looking for work (and/or qualified for social security benefits) are counted as unemployed. Those who have given up looking for work (and sometimes those who are on government retraining programmes) are not officially counted even though they are unemployed. The same applies to those who have taken early retirement to avoid being laid off, but would prefer to be working.

\section{Causes Of Unemployment In Nigeria}

1. Neglect of the Agricultural Sector: The agricultural sector has been the leading provider of employment in Nigeria, especially in the sixties and in the seventies when the sector provided employment for more than 60 percent of the Nigerian population. However, unfortunately, in the wake of oil discovery, the attention on this anchor of the economy was drawn away to the oil sector where employment capacity is very low. The resulting effect is the large number of job seekers who have no place in the oil industry. Even with the expansion of the industry, unemployment has continued to grow at an alarming rate. Until early 1970s, agriculture remained as the mainstay of the Nigerian economy. It constituted the major income earner for the country and the largest employer of labour as over 90 percent of the populace worked and earned their daily income from this sector.

2. Systemic Problems in Education: Most people have blamed the falling standard of education in the country for the rising unemployment in Nigeria. It has been argued that many universities and other tertiary institutions churn out half-baked products in their thousands who are hardly suitable for the labour market or gainful employment. Some educationists refute such assertion, and have argued that "where there are half-baked products from our universities, know that the problem is systemic". Turning the blame back to the government, Ndifon (2009) argued that the curriculum has not been planned to meet with the present day realities and in most cases there are poor facilities and sometimes none with which to train the students. In the same vein, Samuel (2011) dictum that the educational system laid much emphasis on certificate acquisition while neglecting the application of the knowledge and skills acquired to meet the challenges of the contemporary Nigeria. However, Ogunlade (2007) blamed the systemic problem in Nigeria educational system on the colonial legacy which continues to rub shoulders and even persist as the order of the day in contemporary Nigeria. The negative public attitude or prejudice against agriculture still persist.

3. Lack of enabling Environment: The poor economic and lack of enabling environment that have characterized the economy over the years have continued to pose serious challenges to employment generation in Nigeria. This, coupled with poor security environment has continued to hamper investment drives and thereby reducing the 
prospects of employment generation. Many job seekers who would have embarked on self- employment programs are unable to do so because of the hostile production environment. Others who make attempt are forced to wind up due to absence of infrastructures and the overall heat of the investment environment. The Government has not created the enabling environment for the unemployed Nigerians to create jobs or small scale businesses for themselves. The hostile business environment precipitated by poor infrastructure, particularly poor power and water supply, and trade policies which allow all kinds of imported goods to flood the country have created high unemployment rate in the country.

Many artisans who cannot afford power generators have been forced to remain idle. Successive governments have allocated resources to the power sector in last two decades, yet the target 4000 megawatts have not been met. Recently, it was announced that the country's generation capacity has fallen to about 2000 megawatts. This megawatt is grossly inadequate even for domestic purposes. Roads and rail connectivity are moribund and inefficient. Entrepreneurship has been systematically desensitized because small businesses that have limited access to capital and political connections are forced to collapse. The causes of unemployment in Nigeria are inexhaustible.

4. Wrong Impression About Technical And Vocational Studies: The wrong impression of students about the place of technical and vocational education also accounts for the deteriorating state of unemployment in Nigeria. There is an enduring societal biased attitude against technical and vocational education. A large number of job seekers lack practical skills that could enhance self - employment. That is why rather than providing jobs for others, the graduate unemployed persons keep depending on the government and the non-vibrant private sector for job offers (Bello, 2003).

5. Adoption of Untimely Economic Policy Measures: Another crucial factor that has elicited unemployment problem overtime is the demise of the small scale and cottage industries which operated in both formal and informal sectors. Following the introduction of the Structural Adjustment Program (SAP) in September 1986 that ushered in liberalization, deregulation and the devaluation program of the domestic currency, many of the teething domestic firms collapsed. This resulted in the loss of many jobs and thereby rendering many people unemployed. Although, these policies were designed to jump start the growth of the economy, but given the structure of the Nigerian economy, some of the policy packages became out rightly inimical to the system due to wrong timing.

6. Corruption: Corruption is not a strange word to an average Nigerian. Simply put, it is a dishonest or illegal behavior, especially of people in authority. It is an abuse of public office for private gain which usually involves embezzlement of public funds, nepotism and falsification of facts and figures, etc. Corruption has no doubt done incalculable damage to every facets of the country, Nigeria. It has undermined democratic institutions, retarded economic growth and development (Samuel, 2011); and caused poverty in the midst of plenty, it has prevented the country from making political, social and economic progress and ultimately brought about high level of mass unemployment in the country. It has denied millions of Nigerians access to good education, housing, health, food and infrastructure (National Standard, Oct. 15, 2007).

7. Rural-Urban Migration: The rapidly growing urban labor force, arising from rural urban migration has been identified as a cause of unemployment. Rural-urban migration is usually explained in terms of push-pull factors. The push factors include the pressure resulting from man-land ratio in the rural areas and the existence of 
serious underemployment arising from the seasonal cycle of climate (Okafor, 2011). The factors are further exacerbated in Nigeria by the lack of infrastructural facilities, which makes the rural life unattractive. As a result, millions of youths move to urban areas with the hope of securing lucrative employments in industries and also to be able to access the social amenities that abound in the urban centers. The implication of this have been that most rural areas have remained neglected in the allocation of social and economic resources

8. Gradual Collapse of the Manufacturing Sector: The absence is of a vibrant manufacturing sector which has the capacity to absorb the mass of the unemployed youths in Nigeria is also implicated. There are over 800 collapsed industries in Nigeria today and over 37 factories closed shop since 2009. About half of the remaining operating firms have been classified as "ailing," a situation that poses a great threat to the survival of the manufacturing sector in the country in the next few years. According to a survey carried out as part of its membership operational audit in January 2010 by the Manufacturers Association of Nigeria (MAN), the 834 figure represents the cumulative aggregate of firms that have shut down their operations in 2009 across the country.

The MAN survey covered five manufacturing enclaves, into which the country is divided, in terms of manufacturing activities. These include the Lagos, northern, southeast, south-south and southwest areas. The report of the survey showed that in 2009, a total number of 176 firms became terminally sick and collapsed in the northern area. In the southeast area, a total number of 178 companies were shut down during the period. While in the south-south area, 46 companies shut down operations before December 2009. According to the survey, the southwest area lost 225 companies during the year. It said that the Lagos area, followed closely with 214 manufacturing firms closing shop before the end of 2009 (Okafor, 2011).

It is indeed worrisome for a country like Nigeria, with all the resources at her disposal, having over 61 million (37\%) unemployed, and over $70 \%$ of the populations living below poverty line, whilst its leadership at all levels amass ill-gotten wealth with impunity. It is a popular belief that ascription and nepotism permeates job placement in both private and public sectors. In the labour market today, 'who you know' and 'how much you can pay' determines one's chances of securing employment, rather than merit. This has denied well qualified, determined and energetic Nigerians employment.

\section{Effects Of Unemployment}

According to Bello (2003) the consequences of unemployment in Nigeria are very severe and threatening to the citizenry and the economy as a whole. The unemployment scourge has continued to pose so many challenges to the survival of the Nigerian nation. While some of these consequences bother directly on the unemployed, others like epidemic are limitless in its effects. They include:

1. Contributes to low GDP: It is an established economic reality that the size of the workforce directly impacts a country's GDP. Not only does the work force produce manufactured goods or services or agricultural produce in direct proportion, but also brings in its wake increasing purchasing power, which in turn, fuels economic growth. Thus unemployment contributes to a reduction in the potential which exists in spurring a country's GDP. 
2. Contributes to crime and violence: With growing youth unemployment, the divide between the rich and the poor grows, resulting in social tensions which have affected the entire fabric of communities, states and the entire country (Niger-Delta).

3. Contributes to drug abuse: Due to frustration as a result of not being gainfully employed, most youths turn to drugs.

4. Unproductive labour force: The most direct impact on the economy of an unproductive labour force is lost output in terms of goods and services. With no income tax to collect and the loss of receipts from indirect taxes such as the value added tax, the government takes in less in tax revenue..

5. Psychological effects: Young men and women, who have put in a decade or two in schools and colleges, have dreams and aspirations. These are dreams of securing satisfying jobs following their years of struggle, meeting basic necessities of life (food, clothing, shelter and healthcare), graduating to a life of comfort and dignity and, eventually, enjoying the luxuries of life. The trauma of seeing their dreams shattered week after week, month after month, can and does lead to deep psychological scars that are very difficult to face at such a young age. These have affected many individuals selfesteem and have led to their suffering from depression.

6. Law and order: It has been established that the educated but unemployed are likely to take to crime- blue collar or white collar crimes- more easily than others. This arises out of the theory that they would have, at some stage of their careers, seen good life, even from a distance, and formed their dreams based thereon. When they fail to see these dreams turn into reality, many of them turn to crime.

7. Effects on health: It is equally easy to visualize that the lack of steady income could, apart from the above ills, also lead to inadequate nutrition which adversely affect the health of youths and their families.

8. Political instability: When unemployment grows in a community, dissatisfaction with the incumbent Government follows. This, in turn, leads to frequent changes in Governments or formation of unsteady coalitions. Neither is healthy for long term stable economic policies and this situation often lead to a vicious circle of political changes. As President Franklin D. Roosevelt once stated, "Not only our future economic soundness but the very soundness of our democratic institutions depends on the determination of our government to give employment to idle men."

\section{THEORETICAL FRAMEWORK}

There are divergent views by scholars in economics on the theoretical bases of unemployment. However, two prominent schools of thoughts will be applied in this work to discuss the multidimensional issue of unemployment in Nigeria. These are the Keynesian Economic theory and the Marxist Theory of unemployment.

\section{THE KEYNESIAN UNEMPLOYMENT THEORY}

This theory is also called the cyclical or deficient-demand unemployment theory. The cyclical or Keynesian economists hold the view that unemployment occurs when there is not enough aggregate demand in the economy to provide job for everyone who wants to work. According to these economists "when demand for most goods and services falls, less production is needed and consequently fewer workers are needed, wages are sticky and do not fall to meet the equilibrium level, and mass unemployment results.

The name cyclical is derived from the "frequent shift in the business cycle, although unemployment can also be persistent". For instance, the decade of the 1930s saw the Great Depression impact on labour market across the globe. In Germany for instance, the 
unemployment rate reached nearly $25 \%$ in 1932 . In some towns and cities in the north-east of England, unemployment reached as high as 70\%; Canada reached 27\% at the depth of the depression in 1933. The United States unemployment rate averaged 3\% in 1929, but in 1933, $25 \%$ of all American workers and $37 \%$ of all non-farm workers were unemployed. More recently, history repeated itself again when more than 25 million people in the world 30 richest countries lost their jobs and joined the already unemployment market between 2007 and the end of 2010, as the global economic downturn pushed most countries into another wave of recession.

Nigeria seems to be one of the worst hit. For instance, while many government agencies and Parastatals placed embargo on employment in the last two decades, within the same period, governmental reforms disengaged about 121,731 workers from the public service between 2006 and 2007.

During the first phase of the rightsizing process of the 2005 public service reform, about 30,000 officers of the core civil service were disengaged from service. (Adegoroye, 2006). The banking industry also suffered adverse effects of the financial crisis. A Bank in the sector massively 'swept out' their work force in a bid to remain in business and this has drastically increased the rate of unemployment in Nigeria. The Keynesian economists argue further that since the number of unemployed workers exceeds the number of job vacancies, even if full employment were attained and all open jobs were filled, some workers would still remain unemployed due to some mismatch in the economy. Some associate this theory with frictional unemployment because the factors that cause the friction are partly due to cyclical variables. For example, a surprise decrease in the money supply may shock rational economic actors and suddenly inhibit aggregate demand.

Hence, Keynesian economists see the lack of demand for jobs as potentially resolvable by government intervention. Their prescription for reducing unemployment is deficit spending by government to boost employment and increase in aggregate total demand. They further suggested intervention through an expansionary monetary policy that increase the rates thereby leading to an increase in non-government spending (Haris, 2005), and policies that encourage more private investment (Obadan \& Odusola, 2010).

\section{MARXIST THEORY OF UNEMPLOYMENT}

This theory was developed by Karl Marx in 1863. From his Theory of Surplus Value comes the citation below:

"It is the very nature of the capitalist mode of production to overwork some workerss while keeping the rest as a reserve army of unemployed paupers."

\section{(Karl Marx, 1863)}

Karl Marx, in this theory, believes that unemployment is inherent within the unstable capitalist system and periodic crises of mass unemployment are to be expected. Capitalism, to the Marxists, unfairly manipulates the labour market by perpetuating unemployment which lowers laborers demand for fair wages. Workers are pitted against one another with the motive of increasing profits for their employees. In the conception of Karl Marx, the only way to permanently eliminate unemployment would be to abolish capitalism and the system of forced competition for wages, and then shift to the socialist or communist economic system. 
For the contemporary Marxists, the existence of persistent unemployment is a proof of inability of capitalism to ensure full employment.

The socio-economic distress the Nigerian citizens faced under colonialism led the populace to clamor for socialism as advocated by the Marxists. The socialist movement was initially a reaction against extreme poverty caused by capitalism on the masses. It laid great emphasis on the state embarking on a broad programme of welfare for the people, "the programme that would provide social insurance to protect the masses against unemployment and economic distress"; for instance, the post-independent Africa preached socialism. The NCNC government under Dr. Nnamdi Azikiwe and Dr. Michael Opara, preached "Welfarism and Pragmatic Socialism". The Action Group, under Chief Obafemi Awolowo advocated "Democratic Socialism". And in Ghana, under Dr. Kwame Nkrumah, many state industries were instituted (Udu \& Agu, 2005).

However, the present day Nigeria seems to be taking a leap at mixed economic system due to low impact of capitalism and socialism to bring about real economic growth and development. Developing countries of which Nigeria is one, are calling on both the government and private sectors to cooperate and develop the country's economy. In recent times, the government is adopting the public-private partnership initiative with the hope of achieving and accelerating some developmental objectives. Pivoting the economy cannot be left in the hands of the private sector alone; therefore there is the need for the government to participate fully.

Asaju (2014), had strongly posited that full participation of government in running the economy through its fiscal policy will ameliorate Nigeria's numerous economic challenges especially poverty, unemployment and corruption.

\section{RECOMMENDATIONS}

1. The recruitment of thousands of unemployed Nigerians by all the security organizations of government like the Army, the Airforce, the Police, and other security agencies would go a long way in alleviating the unacceptable unemployment situation in the country.

2. Government should make provision for bail-out funds for both private and public companies and industries whose collapse or closure have rendered their workforce jobless. The environment should be made conducive to make them function effectively.

3. The Agricultural sector should be given proper attention. Government at all levels should recognize the activities of rural farmers. Agricultural loans and other farm inputs such as fertilizer should be released on time and be made accessible to the rural farmers during farming season.

4. The unemployment situation in Nigeria has become a national crisis and a reliance on the private sector to bring the country out this guagmire would only amount to scratchng the surface. The visible hand of the Nigerian government is therefore required to salvage the situation and halt the rising spate of unemployment. The Government should create an enabling environment for Small and Medium scale Enterprises (SMEs) to thrive as it is known world- wide as the engine growth for every economy. The government and private individuals should provide start-up capital in form of loans or grants to those who want to go into business and become self-reliant or self-employed and consequently employ others.

5. The Non-governmental organizations should collectively join hands with government agencies in organizing seminars and workshops geared towards training the unemployed to explore their environment and God-given resources, with a view to helping them maximize their potentials and become self-reliant. The educational system 
should be made functional. To achieve this, emphasis should be laid on entrepreneurship education so that students would have acquired the basic skills needed for self-reliance before graduation from universities or secondary schools.

6. Vocational guidance and counseling services should be given to students in the course of their studies in order to prepare, guide and encourage them to read courses that would guarantee them employment after graduation.

7. There is need to encourage more private- partnership participation in the economy, as this will in the long run help in developing the nation's economy. Government should set standards and ensure that these standards are followed in order to regulate the exploitative tendencies of the private sector, and also provide an environment conducive for them to operate.

\section{CONCLUSION}

The incidence of unemployment in Nigeria in this 21st century is alarming. The rates keep increasing without any appreciable effort to cushion the effects on the army of the unemployed. Nigeria is ranked the 6th largest oil producer in the world. Yet, the country's unemployment rate is one of the highest in the world. The implications of the high rate of unemployment in Nigeria cannot be overemphasized. Unemployment in has become one of the most critical problems the country is facing presently. Years of corruption, civil war, military rule, and mismanagement have hindered the economic growth of the country. Despite being endowed with diverse and infinite resources, both human and material, years of negligence and adverse policies have led to the under-utilization of these resources. The leadership at the federal, state and local government, as well as policy makers must think outside the box and throw up great innovations and new ideas that will help to reduce the rate of unemployment in the country. Nigeria needs to adopt a skill-oriented educational Curricula, that will train the required skilled technical manpower, that will help build and maintain its critical infrastructures that are badly needed to drive the nation' economy and also, to create employment. Nigeria's reserve army of the unemployed as it today, is a time bomb in waiting. It should not be allowed to explode. The time to solve the crisis of unemployment is now. Tomorrow may be too late.

\section{References}

Adegoroye, G. (2006). Public Service Reform for Sustainable Development: The Nigerian Experience. A keynote Address delivered at the Commonwealth Advance Seminar, Wellington, New Zealand. 20th Feb- 3rd March. Bureau of Public Service Reforms

Alanana, O.O. (2003). Youth Unemployment in Nigeria: Some Implications for the Third Millennium. Global Journal of Social Science, 2, (1), 21-26.

Asaju, K., Adagba, S. O. \& Kajang, T. J. (2014). The Efficacy of Fiscal Policy in promoting Economic Growth and Poverty Reduction in Nigeria. Research in World Economy, 5(1): 33-44

Bellemare, D., \& Poulin-Simon, L. 1994. “What is the Real Cost of Unemployment in Canada?" Canadian Centre for Policy Alternatives, Ottawa.

Bello, T. (2003). Attacking unemployment hurdles in the fragile economies of the Sub - Saharan Africa: the experience of Nigeria. A Paper Presented At the - Economics for the Future - Conference; On The Occasion Of the Celebration of 100 Years of Cambridge Economics; Cambridge, United Kingdom September.

Ekpo, A. (2014). Nigeria, the unemployed and the waiting timed bomb. Tell Magazine, May 5, 2014 , no 18.

Haris, S. E. (2005). The New Economic: Keynes' Influence on Theory and Public Policy. Whitefish: Kessigner Publishing.

Harold, G. (2009). Unemployment. Microsoft Encarta. Redmond: Microsoft Corporation.

Hornby. A. S. (2010). Oxford Advanced Learner's Dictionary of Current English. Oxford: Oxford University Press. 
International Labour Organisation (2012). Global employment trends for youth 2012. Retrieved on 12/11/2016 http://www.ilo.org/wcmsp5/groups/public/...dgreports/---dcomm/documents/publication/wcms-180976.pdf

National Bureau of Statistics (2016). Unemployment/ under-employment watch Q1 2016.

http://www.nigerianstat.gov.ng/

Ndifon, X, (2009). Exclusive interview on "The problem of Unemployment in Nigeria". Fountain Magazine 44 ed. December, 2009:15-17

Obadan, M. I. \& Odusola, F. A. (2010). Productivity and Unemployment. Ibadan: National Centre for Economic Management and Administration.

Obiagwu, C. (2014). Recruitment tragedy: 'NIS is liable'. http://www.vanguardngr.com/2014/03/recruitmenttragedy-nis-liable/

Ogunlade, O. F. (2007). British Colonial Education Policy at Home and Abroad: Implication for present day Nigeria Educational System. Journal of Educational Research and Development, 2(3): 24-30.

Proshare (2016, December 13). FDC Aligns With FSDH, Projects Headline Inflation To Creep Up To 18.4\%. https://www.proshareng.com/news/Nigeria\%20Economy/FDC-Aligns-With-FSDH--Projects-Headline-InflationTo-Creep-Up-To-18.4Percent-/33221

Samuel, A. (2011). The Democratic Challenges in Nigeria and The steps toward achieving the Vision 20:20:20. Kubani Journal of Atrs and Social Sciences, 1(1): 14-22.

Samuel, A. (2011). Moral Education as a Tool for Global Change. A Journal of Association of Nigerian Educators, 6(1):183-188.

Udu, E. \& Agu, G.A. (2005). New System Economics. Onitsha; Africana First Publishers Ltd.

United Nations (2016). REPORT: United Nations World Youth Report.

http://www.youtheconomicopportunities.org/resource/5023/report-united-nations-world-youth-report-july2016http://www.youtheconomicopportunities.org/resource/5023/report-united-nations-world-youth-reportjuly-2016

Vanguard (2016, November 2). 700,000 apply for 500 FIRS jobs.

http://www.vanguardngr.com/2016/11/700000-apply-500-firs-jobs/ 